\title{
Anxiety and Perceived English and French Language Competence of Education Students
}

\author{
CAMERON MONTGOMERY \\ University of Ottawa \\ THOMAS SPALDING \\ University of Alberta
}

\begin{abstract}
The authors examined manifest anxiety and perceptions of English and French language competence among Anglophone $(n=35)$, Francophone $(n=29)$, and Mixed-heritage $(n=34)$ elementary education (60\%) and secondary education (40\%) students ( $80 \%$ female) in their second, third, or fourth year of study at the Faculté Saint Jean (University of Alberta). Participants assessed their language competence differently in English and French. Francophone and Mixed-heritage students felt equally competent in the two languages, but Anglophone students reported much higher language competence in English. Manifest anxiety and self-assessments of language competence were related only among the Anglophone group, with high levels of manifest anxiety associated with both low self-assessments of French language competence and high selfassessments of English language competence-the two being correlated with each other.
\end{abstract}




\section{RESUMÉ}

Nous avons examiné l'anxiété latente et les perceptions de la compétence languagière en Anglais et en Français chez des étudiants anglophones $(n=35)$, francophones $(n=29)$ et mixtes $(n=35)$ en enseignement primaire (60\%) et secondaire (40\%) en première, deuxième, troisième et quatrième années à l'université de l'Alberta. Les sujets ont évalué leur compétence langagière en anglais et en français de manière différente. Les étudiants francophones et les étudiants mixtes se sentent compétents de manière égale dans les deux langues alors que les étudiants anglophones évoquent un niveau de compétence en Anglais bien supérieur à celui du Français. L'anxiété latente et les perceptions de la compétence languagière étaient associées négativement seulement chez les étudiants anglophones.

\section{INTRODUCTION}

With increased globalization, many people have realized that knowing more than one language is highly valuable in both personal and professional spheres. Second language learning increased over the course of the 1970s, with enrollment in a foreign language class becoming an essential part of college students' programs of study beginning in the 1980s (Ortega, 2001). Partly because of the increasing importance of second language acquisition, many researchers have investigated the difficulties that people encounter in second language learning (Bailey, Daley, \& Onwuegbuzie, 1999; Bailey, Onwuegbuzie, \& Daley, 1998; Campbell \& Ortiz, 1991; Gardner \& MacIntyre, 1993; MacIntyre \& Gardner, 1991a; Onwuegbuzie, Bailey \& Daley, 1999a; Young, 1991). According to this research, anxiety may be a part of the difficulty that learners have in acquiring another language; however, there are some studies that appear to indicate that there are various types of anxiety and that it can be beneficial (Kleinmann, 1977). Kleinmann found that facilitating anxiety, as measured by the Halpern self-report questionnaire, helped foreign language students by encouraging them to use difficult new structures in the second language. There are divergent views regarding the role of anxiety in second language 
acquisition. The study reported here is focused on manifest anxiety, selfassessment of language competence in English and French language situations, and the relationship between these two variables in university students among elementary and secondary education at Faculté Saint Jean, University of Alberta in a Francophone ${ }^{1}$ minority environment.

\section{Anxiety}

Anxiety may be manifest in various stressful situations (Spielberger, 1983), including higher education (Campbell \& Ortiz, 1991). Anxiety often shows up as overt symptoms such as agitation, restlessness, reduced attention, and wringing of hands (Corsini, 2001). High levels of anxiety have been shown to inhibit or impair cognitive functioning, disrupt memory, lead to avoidance behavior, and to have several negative physiological effects (Eysenck, 1979). Thus, anxiety has many effects across a variety of situations, including second language learning (Campbell \& Ortiz, 1991; MacIntyre \& Gardner, 1991a, 1991b). Similarly, Horwitz, Horwitz, and Cope (1986) claimed that high anxiety may account for more academic failure than other reasons such as poor study habits, previous weak academic results, or a lack of motivation.

\section{Anxiety and Second Language Acquisition}

According to Onwuegbuzie et al. (1999a), individuals who suffer from anxiety in second language situations may show physiological signs such as perspiration, dry mouth, wet hands, general tension, muscle contraction, and increased heartbeat. Other signs may be of a behavioural nature, such as avoiding classes, refusing to complete homework, and the concern that fellow students' levels of performance are superior (Horwitz et al., 1986). Indeed, Horwitz, et al. (1986) claimed that, from a clinical perspective, the anxiety associated with second language learning should lead to the same subjective feelings, psycho-physiological symptoms, and behavioral responses as anxiety in any other educational setting.

Not all effects of anxiety are necessarily negative. For example, MacIntyre (1995) suggested that a medium level of anxiety would improve language performance. MacIntyre, Noels, and Clément (1997) added that 
students who are anxious have a tendency to underestimate their language abilities, whereas those who are seemingly more relaxed have a tendency to overestimate their abilities. Such an effect (assuming the anxiety level is not too high) could lead to slightly anxious students working harder to learn a second language, whereas those who feel low levels of anxiety may not be motivated to work as hard. Similarly, Daley, Onwuegbuzie, and Bailey (1997) found that students who have low expectations of their foreign language ability tend to have low levels of foreign language achievement, which may reflect an accurate perception of their foreign language ability; however, as stated by the authors, caution is necessary here because this finding suggests the possibility of a self-fulfilling prophecy, in which students who have low expectations of their foreign language ability exhibit behavior that attenuates their levels of performance, much as students who are very low in anxiety may overestimate their language abilities (MacIntyre et al., 1997).

Unfortunately, second language learning does appear to involve relatively high levels of anxiety. For example, Campbell and Ortiz (1991) estimated that more than one-half of university students studying second language, regardless of the language major, have high levels of language anxiety. In fact, more recent research has established that second language acquisition in second language learners is related to a high level of anxiety in comparison with other university courses (Onwuegbuzie et al., 1999a). Such anxiety may determine perseverance, motivation, and interest in studying a foreign language. Other authors are more specific, stating that second language courses in French cause more anxiety than do mathematics and English courses, thus causing many undesirable effects such as feelings of helplessness and lack of motivation (MacIntyre \& Gardner, 1989). Ganschow, Sparks, Anderson, Javorshy, Skinner, and Patton (1994) supported the belief that high levels of anxiety negatively affect second language acquisition. More specifically, their results indicated that high anxiety students may exhibit poorer language skills and foreign language aptitude than do low anxiety students. Onwuegbuzie et al. (1999b) also suggested that there is a negative correlation between anxiety and selfconfidence in second language learning. MacIntyre and Gardner (1991a, 1991b) found that anxiety is related to both self-confidence and motivation 
to learn a language. Similarly, certain highly anxious students sometimes attribute language-acquisition difficulties to low intelligence, which may provoke second language abandonment (Ganschow et al., 1994).

Bailey, Onwuegbuzie and Daley (2000), used path analysis to test what the called the Anxiety-Expectation Mediation (AEM) model of foreign language learning, in which two individual difference variables (i.e., anxiety and expectation of foreign language achievement) play a central role in predicting foreign language performance. Moreover, in this model, anxiety and expectation mediate the relationship between foreign language achievement and other cognitive, personality, and demographic variables. These authors found a direct negative effect on anxiety on foreign language achievement, as well as a direct negative effect of foreign language achievement on anxiety. In other words, anxiety and foreign language achievement were reciprocally related. In addition, anxiety mediated the relationship between foreign language achievement and the following variables: gender, overall academic achievement, perceived global selfworth, and students' expectations of their achievement levels in foreign language courses. Also, there was a direct positive path from students' expectations to foreign language achievement. Furthermore, expectation moderated the relationship between achievement and age, perceived global self-worth, anxiety, and grade point average. Thus, the AEM model suggested that both anxiety and self-efficacy play an important role in the foreign language learning context.

\section{Anxiety and Environment}

Achieving satisfactory second language competence is usually a long and elaborate process comprising both theoretical courses and social interactions. For example, when looking at this process, Landry and Allard (1990) revealed that it does not suffice simply to attend classes, because the interpersonal network of language contacts is crucial. According to these same authors, academic, family, and social-institutional environments have a seemingly positive effect upon developing language competence and bilingualism. Thus, the frequency of use of the first and second languages in these three environments may determine the degree of competence and assimilation of second language learners. Further, individuals learn the 
importance of their language by the intermediary of the family from which social identity is established (Landry \& Allard, 1990).

In addition to the family, social support within the community may be very important in first and second language learning and development. In fact, the ability of the community to create and maintain interactions in French within the Francophone language minority has proved to be a key variable in self-assessment of language ability (Landry \& Allard, 1997) in Francophones who come from communities where there is a strong feeling of ethnic vitality. Francophones claim greater ease and use of French in various social contexts than those coming from a community where the feeling of ethnic identity is weaker. One may therefore question what selfassessments would be of French language competence for Anglophones learning French in a Francophone minority environment.

\section{Research Rationale and Purpose}

The linguistic environment, whether it is an English majority or a French majority linguistic environment, influences language anxiety and the potential loss of a first or second language, particularly in a linguistic minority environment where the majority language dominates in terms of social networks, media, and school. Tardif (1990) suggested, therefore, examining the relationship between anxiety and French language competence in Francophone and Anglophone populations at the university level to understand better such negative effects as French language abandonment in minority Francophone environments. The rationale of our study is to examine the relationship between anxiety and self-assessments of English and French language competence with a population ( e.g., Francophone minority in western Canada) and research instruments that have never been used before in this context. In fact, few, if any researchers, to date, have examined the relationship between anxiety and French language competence in Francophone and Anglophone populations at the university level in a Francophone minority environment in western Canada.

In this study, we examined the relationship between anxiety and selfassessments of English and French language competence as reported by participants in a Francophone minority environment. More specifically, the 
aim was to examine anxiety and self-assessments of language competence in English and French language situations among Francophone (both parents speak French), Anglophone (both parents speak English), and Mixed-heritage (parents speak different languages ${ }^{2}$ ) university students in elementary and secondary education at Faculté Saint Jean, University of Alberta.

\section{Research Questions}

What are Anglophone, Francophone, and Mixed-heritage education students' self-assessments of their levels of competence in English and French language situations?

What is the relationship between anxiety and self-assessments of competence in English and French language situations among Anglophone, Francophone, and Mixed-heritage education students?

\section{METHOD}

\section{Sample and Procedure}

Two questionnaires were distributed to 88 education students at the Faculté Saint Jean, University of Alberta, at the beginning of the fall 2001 semester. The participants consisted of elementary ${ }^{3}$ education students in their second, third, or fourth years representing $60 \%$ of the total sample, and secondary ${ }^{4}$ education students in their second, third, or fourth year of study representing $40 \%$ of the total sample for a total of 88 students. Education students were chosen for this study because of the emphasis that is put on mastering oral and written French in order to teach in this language. It is worth noting that student-teachers have increasing teaching responsibilities at the Faculté Saint Jean, University of Alberta, over the course of their program. The majority (89\%) of education students were in their third and fourth years. The majority (70\%) of the students' ages ranged between 19 and 24 years old, and the sample was 80\% female. Students were classified according to the language of origin of their parents such as:

- Both parents are Anglophone $(n=35)$

- Both are Francophone $(n=29)$

- Parents are of Mixed-heritage $(n=24)$ 


\section{Research Context}

Education students who participated in this study were enrolled at a Francophone faculty (Faculté Saint Jean) that is a part of a majority Anglophone University (University of Alberta). Many programs are offered at this Francophone faculty and the most popular field of study is Education. Instruction is strictly in French. Students must pass a written and oral French exam upon entry into the education program (primary and secondary); therefore there is a screening process in terms of French competence. As we explain later, many education students have previously studied in French immersion (Anglophone and Mixed-heritage students) classes, whereas Francophone as well as certain Mixed-heritage students (coming from exogamous families) came from diverse Francophone environments ( e.g.,, France, Africa, province of Québec) and schools. The province of Alberta and city of Edmonton where this French Faculty is situated is a majority Anglophone environment.

\section{Instruments}

Two questionnaires were administered in French. The first measured manifest anxiety, and the second measured self-assessments of oral competence in French and English. The manifest anxiety questionnaire contained 11 items (see appendix A), and measured one overall dimension of anxiety (a form of trait anxiety) that is manifest in stressful situations such as second language learning, and that was confirmed and validated in French in a former study by Montgomery, Bujold, Bertrand and Dupuis (2002). ${ }^{5}$ High scores on this scale represent high levels of manifest anxiety.

Participants took, on average, five minutes to respond to this questionnaire. An item analysis revealed, however, that four questions had a weak item-total correlation. A weak item-total correlation was considered as being less than 0.4. Thus, the following four questions were eliminated: "I have confidence in myself," "I am calm, I rarely become angry," "I have difficulty concentrating on my work," and "I don't like confronting difficulties or making an important decision.” The internal consistency (Cronbach's alpha) of the scale scores rose from 0.63 to 0.76 
after eliminating these four items. The manifest anxiety scale was used in order to determine when anxiety would in fact manifest itself as the name implies. Although some research has moved away from such general scales to more specific language anxiety scales, former research (Bujold, 1991; Montgomery et al., 2002) with the manifest anxiety research instrument has provided valid results with education student populations in terms of predicting and detecting anxiety before and after student teaching. Moreover, the manifest anxiety research instrument is appropriate for our research purposes because it is a measure indicating the extent to which a person is likely to respond to stressors in an anxious way. The stressors, in this case, are second language speaking situations.

For the second questionnaire, also in French, we used the work of Landry and Allard (1997). These researchers constructed a test to examine exogamy and the maintenance of two languages and two cultures in a bilingual context among high school students in New Brunswick. One of their questionnaires was designed to measure self-assessments of oral competence in everyday French and English language situations. In this questionnaire, participants assessed their own oral competence in French and English with 12 communication situations for a combined total of 24 questions. These situations varied from simple to complex. The participants indicated their responses separately for standard French and English; that is, the ability to communicate in each situation, [1 = large difficulty (very little communication possible), 5 = moderate difficulty, 9 = large facility (easy and natural communication)]. This test took, on average, ten minutes to administer. The internal consistency (Cronbach's alpha) of the scale scores yielded by the second instrument was 0.93 .

\section{Open-ended Item}

Finally, at the end of the two questionnaires, participants responded to one open-ended item asking them in which language situations they felt anxious in either English or French. The method of constant comparison was used to extract the themes (see Glaser \& Strauss, 1967). Three judges categorized responses separately and compared results in order to insure dependability and confirmability of the categories. Among these three 
judges were a fourth-year languages student, a fourth year psychology student, and a professor in educational psychology who supervised the categorisation process. Consensus was reached through negotiation and discussion thus insuring the credibility of the categories. It was then decided which language situations provoked anxiety regardless of the language (French and/or English combined) in order to have a global portrait of anxiety-inducing language situations in this population. We present categories that will explain in the Findings section that follows.

\section{FINDINGS}

Analyses were conducted using sex, program, and year in program to determine whether these characteristics of the sample led to any differences on the dependant variables of interest. None of the analyses were significant, so the data have been combined across sex, program, and year in program for the following analyses. Moreover, an exploratory factor analysis was conducted to assess the unidimensionality of the manifest anxiety scale. Results will not be presented here but it is worth noting that unidimensionality was indeed confirmed.

\section{Self-assessments of Language Competence}

For the first research question (what are Anglophone, Francophone, and Mixed-heritage education students' self-assessments of their levels of competence in English and French language situations), means were compared for the three groups across English and French language situations using a repeated measures analysis of variance (ANOVA).

The analyses indicated a main effect of language situation and an interaction between language situation and student group. However, as seen in Table 2, the main effect of language situation was driven only by the Anglophone group, $t(33)=7.4, p<.001$; neither the Francophone nor the Mixed groups showed any effect of language situation, both $t$ 's $<1$.

\section{Second Research Question}

To answer the second research question pertaining to the relationship between manifest anxiety and self-assessments of English and French language situations among Anglophone, Francophone, and Mixed-heritage 
Table 1

Estimated means of Perception of English and French Competence of Anglophone, Francophone, and Mixed-heritage University Education Students

\begin{tabular}{lccc}
\hline Participant Groups & $\begin{array}{c}\text { Language Situations } \\
\text { in English }\end{array}$ & $\begin{array}{c}\text { Language } \\
\text { Situations in } \\
\text { French }\end{array}$ & $\begin{array}{c}\text { Estimated } \\
\text { Mean }\end{array}$ \\
\hline Anglophone $(n=35)$ & $8.57 / 10^{\mathrm{a}}$ & $6.62 / 10$ & $7.59 / 10$ \\
Francophone $(n=29)$ & $7.79 / 10$ & $7.84 / 10$ & $7.81 / 10$ \\
Mixed-heritage $(n=24)$ & $7.37 / 10$ & $7.16 / 10$ & $7.27 / 10$ \\
Estimated Mean & $7.98 / 10$ & $7.17 / 10$ & \\
\hline
\end{tabular}

a Based on a scale to 10 .

Table 2

Repeated measures analysis of variance (ANOVA)

\begin{tabular}{|c|c|c|c|c|c|}
\hline Sources of variance & $\begin{array}{l}\text { Degrees of } \\
\text { Freedom }\end{array}$ & $\mathrm{CM}$ & $\mathrm{F}$ & $\mathrm{P}$ & $\begin{array}{c}\text { Eta- } \\
\text { Squared }\end{array}$ \\
\hline & \multicolumn{5}{|c|}{ Inter-participants } \\
\hline Language Groups & 2 & 3.922 & 1.5444 & .220 & .04 \\
\hline \multirow[t]{2}{*}{ Error 1} & 84 & 2.541 & & & \\
\hline & \multicolumn{5}{|c|}{ Intra-participants } \\
\hline Language Situations & 1 & 21.153 & 11.666 & .001 & .12 \\
\hline $\begin{array}{l}\text { Language Situations X } \\
\text { Language Groups }\end{array}$ & 2 & 18.673 & 10.298 & .000 & .20 \\
\hline Error 2 & 84 & 1.813 & & & \\
\hline Total & 173 & & & & \\
\hline
\end{tabular}


education students, a step-wise multiple regression was performed showing that the anxiety level is significantly $(p<.05)$ negatively related to the selfassessments of French language situations, but not to self-assessments of English language situations. The analysis suggested no problems with multi-collinearity, and no problems with order of entry, as the zero-order and partial correlations were nearly identical: French language situation, zero-order $=-.27$, partial $=-.27$ and English language situation, zeroorder $=.03$, partial $=.05$. Although statistically significant, when referring to the French language situation, the relationship was relatively weak, accounting for only about $6 \%$ of the total variance in anxiety. All students were included in this initial analysis; however, given the finding for the first research question, it is likely that the relationship identified in the multiple regression is limited to Anglophone students. However, this was not a hypothesis and this result will be discussed later.

To examine this issue, correlations between manifest anxiety and selfassessments of French and English language competence were examined for Anglophone, Francophone, and Mixed-heritage education students separately.

Only the Anglophone group showed any consistent relationship between manifest anxiety and self-assessed language competence. None of the other groups' correlations were statistically significant. These analyses suggest that the Anglophones are uncomfortable in French language situations compared to English language situations. The negative correlation between anxiety and French language competence indicates that the higher the student's level of anxiety, the lower his or her selfassessment of competence in French language situations. Interestingly, the positive correlation between anxiety and English language competence indicates that the higher the student's level of anxiety, the higher his or her self-assessment of competence in English language situations. It is not simply the case that the high anxiety students assess their levels of competence as low in French language situations (which could reflect a general bias to assess themselves as poor), they also tend to assess their levels of competence as higher in English language situations, relative to the lower anxiety students, though we note that this correlation is quite small. We return to this point in the Discussion. 
Table 3

Correlations between Manifest Anxiety and Perceptions of French and English Language Competence for Anglophone, Francophone, and Mixed-heritage University Education Students

\begin{tabular}{lll}
\hline $\begin{array}{l}\text { Correlations between language competence and } \\
\text { language groups }\end{array}$ & $\begin{array}{l}\text { Correlation } \\
\text { coefficient }\end{array}$ & p-value \\
\hline French Language Situations by participant group & & \\
\hline Anglophone participants $(n=35)$ & $-.448^{*}$ & .007 \\
Francophone participants $(n=29)$ & -.141 & .467 \\
Mixed-heritage participants $(n=24)$ & -.303 & .150 \\
\hline English Language Situations by participant group & & \\
\hline Anglophone participants $(n=35)$ & $.355^{*}$ & .040 \\
Francophone participants $(n=29)$ & .278 & .144 \\
Mixed-heritage participants $(n=24)$ & -.369 & .076 \\
\hline$* \mathrm{p}<.05$ & &
\end{tabular}

\section{Situational Anxiety}

Students' responses concerning language situations (combined English and/or French language situations) in which they felt anxious were categorized into four large categories: Psychological (self), Social (interpersonal), Cognitive (subject), and Language (language). In the first category there is an aspect of introspection whereby the students probe their inner language capacities when interacting or communicating in the language in which they feel weaker. The second category may be defined as social situations in which interaction with others produces anxiety, especially when interacting with "important" or high profile individuals. The third category, Cognitive (subject), is related to language difficulties due to complex themes or subjects. Finally, the fourth category relates to difficulty inherent in second language learning such as "getting the message across" to someone. Similar to the second category, this usually takes place while talking to someone "important" in the given second language. See Table 4 for examples. 
Table 4

Categories of Anxiety in relation to French and English Language Situations (all students combined)

\begin{tabular}{|c|c|c|c|}
\hline Psychological (Self) & Social (Interpersonal) & Cognitive (Subject) & $\begin{array}{c}\text { Linguistic } \\
\text { (Language) }\end{array}$ \\
\hline $\begin{array}{l}\text { Thinking about a } \\
\text { lack of practice } \\
\text { (e.g., returning to } \\
\text { university after a } \\
\text { lapse of time), } \\
\text { - Expressing } \\
\text { personal feelings } \\
\text { (e.g., a conversion } \\
\text { with partner), } \\
\text { - Fear of being } \\
\text { judged or } \\
\text { criticized, } \\
\text { - Thinking about } \\
\text { grammatical } \\
\text { errors, } \\
\text { - Talking about } \\
\text { oneself, } \\
\text { - Tell a personal } \\
\text { experience, } \\
\text { Feeling degraded } \\
\text { because of mother } \\
\text { tongue, } \\
\text { Emotional State } \\
\text { ( e.g., frustration, } \\
\text { shyness). }\end{array}$ & $\begin{array}{l}\text { - Talking to } \\
\text { administrative } \\
\text { people for } \\
\text { services (e.g., } \\
\text { administration), } \\
\text { - Talking before an } \\
\text { audience (especially } \\
\text { when tested), } \\
\text { - Talking to a } \\
\text { respected or } \\
\text { attractive person } \\
\text { (e.g., professor), } \\
\text { - A reaction of } \\
\text { incomprehension of } \\
\text { the other person, } \\
\text { - Group conversation, } \\
\text { - Talking in front of a } \\
\text { group of adults, } \\
\text { Talking in front of } \\
\text { unknown people, } \\
\text { - When others fail to } \\
\text { understand due to } \\
\text { accent, } \\
\text { Talking in front of } \\
\text { colleagues of the } \\
\text { same age, } \\
\text { Obligation to } \\
\text { speak to the second } \\
\text { language. }\end{array}$ & $\begin{array}{l}\text { - A profound } \\
\text { subject (e.g., } \\
\text { politics), } \\
\text { - Complicated } \\
\text { telephone } \\
\text { conversation } \\
\text { (e.g., connecting } \\
\text { the telephone), } \\
\text { - Unknown subject } \\
\text { matter, } \\
\text { - Talking about a } \\
\text { misunderstood } \\
\text { subject, } \\
\text { - Limited time } \\
\text { to respond } \\
\text { to a question } \\
\text { (conversation or } \\
\text { written test), } \\
\text { - New situation. }\end{array}$ & $\begin{array}{l}\text { - } \text { Difficulty to } \\
\text { express oneself } \\
\text { correctly, } \\
\text { - Unprepared } \\
\text { communication, } \\
\text { - Translation } \\
\text { difficulty, } \\
\text { - Language } \\
\text { transfer, } \\
\text { - Unannounced oral } \\
\text { exam, } \\
\text { - Higher level of } \\
\text { competence in } \\
\text { other person, } \\
\text { - Weak vocabulary, } \\
\text { - Language } \\
\text { complexity, } \\
\text { - Language } \\
\text { assessment } \\
\text { (exam), } \\
\text { - Looking for } \\
\text { words (e.g., } \\
\text { discourse or } \\
\text { conversation), } \\
\text { - Being corrected } \\
\text { by the other } \\
\text { person. }\end{array}$ \\
\hline
\end{tabular}

\section{DISCUSSION}

This study was intended to answer two main questions. First, what are Anglophone, Francophone, and Mixed-heritage education students' selfassessments of language competence in French and English language situations? The overall pattern that emerges is one in which Francophone 
and Mixed-heritage students seem to regard themselves as being more bilingual than the Anglophone students. In particular, the Anglophone students report vastly different French and English language competence, while the Francophone and Mixed-heritage students report much smaller differences. The Anglophone students may be over-rating their levels of competence in English language situations based on statistical significance, assigning themselves higher competence in English than the Francophone students assign themselves in French language situations. It is important to underline that these are self-assessments only and it is therefore difficult to draw any definitive conclusions. This pattern could be due to the fact that the Francophone students are in a majority Anglophone environment, and thus, might actually consider their levels of competence in French as not being all that high ( e.g.,, they might feel that their levels of competence in French are low relative to a Francophone in a majority Francophone environment). Further, it could be that Francophones tend to over-rate their levels of L2 fluency and possibly under rate their levels of L1 competence in comparison to the Anglophone students. Whatever the reason may be, the Francophone and Mixed-heritage students clearly consider themselves to be more bilingual than do the Anglophone students. This self-assessment could have important consequences, particularly regarding the extent to which the students will maintain their bilingualism in later life. This would therefore call for a future study with the same research instruments in a majority Francophone environment to compare results.

Second, is there a relationship between manifest anxiety and selfassessments of French and English language competence? Only the Anglophone education students showed any significant relationship between manifest anxiety and language competence. High levels of manifest anxiety were associated with (self-assessed) low French language competence and high English language competence. It is important to underline here the difficulty of establishing a causal link between manifest anxiety and self-assessments of French language situations. It is difficult to make directional claims at this point because it could be that students who are more anxious assess the situations as less comfortable, or it could be that students who are uncomfortable in French situations (self-assessment of incompetence) are therefore more anxious; or they could both influence 
each other, or it could be that there is some other variable that is responsible for both of these. A future study with a specific language anxiety scale may provide insight into these questions because this scale may further confirm results of our study.

The Francophone and Mixed-heritage participant groups are not experiencing manifest anxiety that can be related to self-assessments of language competence. Again, caution is necessary because the nature of the Anglophone students' relationship between anxiety and self-assessed competence in French language situations remains open. This finding may be related to Noels and Cléments' (1997) study, which suggests that students who are anxious have a tendency to underestimate language competence, compared to those who are relaxed, who tend to overestimate their levels of competence.

TheAnglophone group as a whole assesses itself as very highly competent in English language situations (much higher than the Francophones in French language situations), but as having relatively low competence in French language situations. This result may be related to findings in the Price (1991) study, whereby the majority of anxious students believed their language skills were weaker than those of other students. Thus, to return to the question of the nature of the differences in self-assessed competence among the language groups, the significant positive correlation between anxiety and self-assessed English competence in Anglophones suggests that there is an overestimation of English competence, particularly for those Anglophones who are most anxious. Notice that there is no comparable correlation for the Francophone students. For example, if the Francophone students felt that they were less competent (in French language situations) than a Francophone from a majority Francophone environment, then one might expect that more anxious Francophone students would assess their French competence as lower than less-anxious Francophone students. For the Francophone students, however, anxiety had no relation to selfassessed competence in either French or English language situations. Further research which measures actual (rather than self-assessed) levels of language competence may help to clear up this issue. 


\section{Research Implications}

Our results are in accordance with a number of previous studies based on actual second language acquisition that have shown a negative correlation between anxiety and second language acquisition (Ganschow et al., 1994; MacIntyre et al., 1997; Onwuegbuzie et al., 1999a). However, our study was based on perceived second language acquisition. One novel aspect of our study is the finding regarding the differences between the Anglophone and Francophone students' self-assessment of language competence in English and French language situations and its relationship to anxiety. The social environment in which our participants live (that is, a completely Anglophone environment) may limit the number of interactions the Anglophone students have with other French-speakers. This corresponds to McMahon's (1994) and Landry and Allard's (1997) studies, whereby the social environment plays a vital role in achieving language acquisition. Anglophones in this study, therefore, may be limited to French use strictly in an academic setting, thus making learning French more arduous, stressful, and anxiety-provoking. Francophones are a minority in Edmonton, Alberta but they may be receiving more support for using French from several different sources: family, friends, and community. Additionally, of course, because the overall language culture is Anglophone, the Francophone students also have many opportunities for interactions in English language situations. Thus, as the students themselves are reporting, it is quite possible that the Francophone and Mixed-heritage students really are more bilingual than the Anglophone students. If true competence were the only factor, however, one would expect the differences in self-rating to be restricted to the second language. Thus, the fact that Anglophones (and in particular, highly anxious Anglophones) appear to be over-estimating their levels of English competence is important when comparing statistically significant results to other groups. Indeed, these anxious Anglophone students may well be under-estimating the degree of their bilingualism, which could have important effects on the extent to which they are willing to continue to study or use French. This result is relevant when considering Onwuegbuzie et al. (2002) study because both anxiety and self-efficacy play an important role in the foreign language learning context. More specifically, anxiety and self-perceptions may play an important role in 
the foreign language learning context but future studies are necessary to examine this relationship. It would be interesting to study other variables such as confidence (unfortunately it was one of the items eliminated in the manifest anxiety questionnaire), avoidance behavior (Anglophones may not be practicing essential aspects of the French language), and motivation (perhaps Anglophones do not intend to use French outside of the university environment) to have a more complete portrait of the population (see Klienmann, 1977).

\section{Open-ended Item Synthesis}

In terms of students' responses to the open-ended item pertaining to anxiety provoking language situations, anxiety is felt by all three groups, and in similar situations. Students often feel intimidated (Social) when speaking a second language in various social contexts. These social contexts are numerous, but most are related to a state of psychological preparation, or lack thereof, before the actual social interaction occurs. This phenomenon of a feeling of unpreparedness is especially apparent when the situations are complicated (i.e., a complicated subject or theme; Cognitive), or when students feel that other more "important" people may be judging their language competence. Moreover, the category with the highest amount of discourse (responses) is related to interpersonal communication. These results are similar to Price's (1991) qualitative study whereby university students studying French fear public embarrassment. Also, they may be related to MacIntyre and Gardner's (1991a, 1991b) studies indicating that anxiety is related to self-confidence. What is important here is the fact that education students recognize their difficulties within the communication process when they interact or work in the language that is most difficult to them. Second language professors may find some pedagogical and research avenues here. Moreover, an interesting and challenging question for researchers would be the following: could stress and anxiety be due to the status of the language to be learned as well as the structural system or inner system of the language ( e.g.,, difficulty of the grammar)?

The qualitative findings are significant when considering the studied population (student teachers), because they must confront new, spontaneous, and challenging situations that demand considerable improvisation and 
constant social interaction. Further, these results are in accordance with those of Campbell and Ortiz (1991), who claimed that the majority of university students learning a second language experience some kind of anxiety regardless of the language (see also Onwuegbuzie et al., 1999a; Bailey et al., 1998), which is not necessarily present when studying other university courses.

\section{CONCLUSION}

In this study, we looked at anxiety and self-assessments of language competence in English and French language situations, among three different groups (Anglophone, Francophone, Mixed-heritage education students) in a Francophone minority environment. It was found that while all student groups reported some anxiety related to language situations, manifest anxiety was related to perceived language competence only for the Anglophone group. In general, the Francophone and Mixed-heritage groups appear to consider themselves to be much more bilingual than do the Anglophone students. This difference likely results from two factors. First, due to the fact of the Anglophone majority environment, the Francophone and Mixed-heritage students really are likely to be more bilingual than are the Anglophone students; however, Anglophone students may actually underestimate their bilingualism, as high manifest anxiety appears to be associated with the overestimation of English competence for these students. Thus, high manifest anxiety, for the Anglophone students, may reinforce lower levels of competence, and could contribute to the loss of French ability over time. A longitudinal study including the research instruments used in our study with other research instruments specific to language anxiety would be relevant to trace this eventuality.

\section{LIMITATIONS}

\section{Manifest Anxiety Measure: An Explanation}

One apparent limit of our study is that the francophone correlations are not significant, this being the fault of the manifest anxiety scale. However, if in fact the manifest anxiety scale is the problem, one should be seeing essentially random patterns of correlations that make no sense. Moreover, there would be no particular reason for the correlations to relate to the 
average self-assessments in any meaningful way. However, the overall pattern of correlations makes quite a bit of sense. When people are, on average, giving low self-assessments, they are more likely to be dealing with anxiety. When people are comfortable with the language, anxiety should be less of an issue. We may therefore ask the following question: "how does this relate to our findings?"

First, the Mixed-heritage group has lots of different language experience other than English or French and may not be very comfortable in either English or French (as shown by their lower average self-assessments), hence (although not significant) the signs tend to be negative (the higher their manifest anxiety the lower their self-assessment). Second, the Francophones, because they live in Alberta, tend to be very bilingual: they self-assess as quite competent in each language, and so their level of anxiety is not related to their language self-assessment. Finally, amongst Anglophones in French language situations, high anxiety leads to low self assessment, which is not surprising because they are in a Francophone institution (at the time of participation in the study) and thus competence or incompetence in French is probably highly salient to them, and even more so for the anxious students. Finally, the one surprising finding is that the Anglophones have a significant positive correlation between manifest anxiety and self-assessed competence in English, so that high anxiety leads to high self-assessment of competence in English. However, this significant correlation matches well with the fact that the Anglophones are giving themselves, on average, a very high rating in English, quite a bit higher that the Francophones give themselves in French. Even if there were a problem with the manifest anxiety scale, there is still the strange average self-assessment data: we can't blame that on a faulty anxiety scale.

Let us consider, overall, what we might expect in terms of the average self-assessment: Francophones should be good in both languages (because their family is Francophone but the overall environment is Anglophone). The Mixed-heritage group is not as comfortable in either (on average) because their language experience probably often includes English and French with each being second or third languages. Anglophones are expected to be less comfortable with French, since they have only learned it in school. However, their self-assessment in English is surprisingly 
high (why do they think that their English is so much better than the Francophones' think their French is, or their English, for that matter)? Perhaps the Anglophones are just really that much better in English than the Francophones are in French and English. If so, there is no reason to see a positive correlation with anxiety. That correlation suggests that they are over-estimating in their self-assessment (or, worded alternatively, we may be seeing a contrast effect in which their very low French self-assessment pushes them to give a very high English self-assessment, with the high anxiety students more susceptible to this contrast effect.)

In fact, overall, the manifest anxiety scale seems to match well with the self-assessment data across the groups, something that one would not expect if the anxiety scale was really faulty (for this particular application). The Francophones are content with either language because they tend to be truly bilingual, so their anxiety level does not seem to relate much to language. The Mixed-heritage group is not totally comfortable with either language, so there is a tendency to see negative correlations (though not always significant) with anxiety in both languages. The Anglophones feel they are less competent in French, therefore there is a strong negative correlation with anxiety. The Anglophones are also surprisingly high in English self-assessment (higher than Francophones in French) and self assessment in English is positively correlated with manifest anxiety.

In other words, when self-assessment is extremely low (Anglophone French), there is an important negative correlation with anxiety, when it is rather low (both mixed cells), moderate negative correlations were observed (marginal or not significant). When it is relatively high (both Francophone cells), small correlations (not significant) were observed, and when it is very high (Anglophone English), there is an important positive correlation. Therefore, we believe that this is not a totally random relationship. 


\section{NOTES}

1. Francophone refers to individuals speaking French at home. Anglophone refers to English being spoken at home. Mixed-heritage means either English, French, or another language (i.e. Mandarin) spoken at home.

2. The Mixed-heritage student group is composed of a number of specific groups: One parent Anglophone and the other Francophone (11\% of total sample); one Allophone (neither Anglophone nor Francophone) and the other Anglophone (11\%); one Allophone and the other Francophone (2\%); other (3\%).

3. Elementary education is taken to mean kindergarten to Grade 6 .

5. Secondary education is taken to mean Grade 7 to 12 .

6. The manifest anxiety questionnaire is an extract of the MMPI (Minnesota Multiphasic Personality Inventory). Taylor (1951) constructed a questionnaire on anxiety by asking judges to choose items of the MMPI which best represented manifest anxiety. Fifty questions were chosen. After an item analysis and concern for parsimony, Bujold (1991) retained 11 questions, which had the highest item-total correlation in this French version. This 11-item questionnaire was used in his doctoral thesis and he obtained an internal consistency (Cronbach’s alpha) of 0.77.

\section{Author contact information}

Cameron Montgomery

Assistant Professor, Faculty of Education

University of Ottawa, 145 Jean-Jacques Lussier St.

Ottawa, Ontario, Canada, K1N 6N5

cmontgom@uottawa.ca

Thomas Spalding

Associate Professor, Department of Psychology

P217 Biological Sciences Bldg, University of Alberta

Edmonton, Alberta, Canada T6G 2E9

spalding@ualberta.ca 


\section{REFERENCES}

Bailey, P., Daley, C. E., \& Onwuegbuzie, A. J. (1999). Foreign language anxiety and learning style. Foreign Language Annals, 32(1), 63-76.

Bailey, P., Onwuegbuzie, A. J., \& Daley, C. E. (1998). Anxiety about foreign language: comparison of French, Spanish, and German classes. Psychological Reports, 82, 1007-1010.

Bailey, P., Onwuegbuzie, A. J., \& Daley, C. E. (2000). Using learning style to predict foreign language achievement at the college level. System, 28(1), 115133.

Bujold, N. (1991). Style d'intervention pédagogique, relations professeursétudiants et engagement par rapport à la discipline. (Teaching intervention style, professor-student relationships, and commitment to discipline). Doctoral thesis, Université Laval.

Campbell, C. M., \& Ortiz, J. (1991). Helping students overcome foreign language anxiety: a foreign language anxiety workshop. In E. K. Horwitz and D. J. Young (Eds.), Language anxiety: From theory and research to classroom implications (pp. 141-150). Englewood Cliffs, NJ: Prentice Hall.

Corsini, R. J. (2001). The dictionary of psychology. New York: Routledge.

Daley, C. E., Onwuegbuzie, A. J. \& Bailey, P. (November, 1997). Predicting achievement in college-level foreign language courses. Poster session presented at the annual conference of the Mid-South Educational Research Association, Memphis, TN.

Eysenck, M. W. (1979). Anxiety, learning and memory: A reconceptualization. Journal of Research in Personality, 13, 363-385.

Ganschow, L., Sparks, R. L., Anderson, R., Javorshy, J., Skinner, S. \& Patton, J. (1994). Differences in language performance among high-, average-, and lowanxious college foreign language learners. The Modern Language Journal, 78(1), 41-55.

Gardner, R. C., \& MacIntyre, P. D. (1993). On the measurement of affective variation in second language learning. Language Learning, 43, 157-194.

Glaser, B. G., \& Strauss, A. L. (1967). The discovery of grounded theory: Strategies for qualitative research. Chicago: Aldine.

Horwitz E. K., Horwitz M. B., \& Cope J. (1986). Foreign language classroom anxiety. The Modern Language Journal, 70, 125-132.

Kleinmann, H. H. (1977). Avoidance behaviour in adult second language acquisition. Language Learning, 27, 93-107.

Landry, R., \& Allard, R. (1997). L'exogamie et le maintien de deux langues et de deux cultures: le rôle de la francité familioscolaire. Revue des Sciences de l'Education, 23(3), 561- 592.

Landry R., \& Allard R. (1990). Contact des langues et développement bilingue : un modèle macroscopique. La Revue canadienne des langues vivantes, 46(3), 527-553.

Lincoln, Y. S., \& Guba, E. G. (1985). Naturalistic inquiry. Beverly Hills, CA: Sage. 
MacIntyre, P. D., Noels, K. A. \& Clément, R. (1997). Biases in self-ratings of second language proficiency: The role of language anxiety. Language Learning, 47(2), 265-287.

MacIntyre, P. D. (1995). How does anxiety affect second language learning? A reply to Spark and Ganschow. The Modern Language Journal, 79(1), 90-99.

MacIntyre, P. D., \& Gardner, R. C. (1991a). Methods and results in the study of anxiety and language learning: a review of the literature. Language learning, 41(1), 85-117.

MacIntyre, P. D., \& Gardner, R. C. (1991b). Language anxiety: Its relation to other anxieties and to processing in native and second languages. Language Learning, 41, 513-534.

MacIntyre, P. D., \& Gardner, R .C. (1989). Anxiety and second language learning: Toward a theoretical clarification. Language learning, 39(2), 251-275.

McMahon, F. (March, 1994). Pour mieux connaître les foyers exogames. Actes du mini-colloque national sur l'exogamie et les structures d'accueil des immigrants et immigrantes francophones. Fédération des communautés francophones et acadienne du Canada. Commissariat aux langues officielles.

Montgomery, C., Bujold, N., Bertrand, R., \& Dupuis, F. (2002). Étude des caractéristiques psychométriques des indicateurs de stress et de la résolution de problèmes sociaux chez les stagiaires en enseignement (Psychometric characteristics of stress and social problem solving indicators in student teachers). Revue canadienne de l'enseignement supérieur, 22(1), 57-90.

Noels, K. A., \& Clément, R. (May, 1997). Ethnolanguage vitality and the acculturation process: Ethnic identity and adjustment of French and English Canadians in contact. Paper presented in R.Y. Bourhis (chair). Ethnolanguage vitality: Some current directions. Paper presented at the 6 th International Conference on Language and Social Psychology, Ottawa, Canada.

Onwuegbuzie. A.J., Bailey, P., \& Daley, C.E. (2002). The role of foreign language anxiety and students' expectations in foreign language learning. Research in the Schools, 9(1), 33-50

Onwuegbuzie, A. J., Bailey, P., \& Daley, C. E. (1999a). Relationships between anxiety and achievement at three stages of learning a foreign language. Perceptual and Motors Skills, 88, 1085-1093.

Onwuegbuzie, A. J, Bailey, P., \& Daley, C. E. (1999b). Factors associated with foreign language anxiety. Applied Psycholanguages, 20, 217-239.

Ortega, L. (2001). Current options in graduate-level introductory SLA textbooks. Second Language Research, 17(1), 71-89.

Price, M. L. (1991). The subjective experience of foreign language anxiety: Interviews with highly anxious students. In E. K. Horwitz and D. J. Young (Eds.), Language anxiety: From theory and research to classroom implications (pp. 141-150). Englewood Cliffs, NJ: Prentice Hall.

Spielberger, C. D. (1983). Manual for the state-trait anxiety inventory (Form Y). Palo Alto, CA: Consulting Psychologists Press.

Tardif, C. (1990). L'identité socioculturelle de l'élève en milieu minoritaire, Education et francophonie, 27(2), 18-21. 
Education Students'Anxiety and Perceived English and French Language Competence

Taylor, J. A. (1951). The relationship of anxiety to the conditioned eyelid response. Journal of Experimental Psychology, 41, 81-92

Young, D. J. (1991). Creating a low anxiety classroom environment: what does language anxiety research suggest? The Modern Language Journal, 75, 426439. 
Appendix A

QUESTIONNAIRE SUR L’ANXIÉTÉ LATENTE

Répondez aux prochaines questions en utilisant la légende qui suit :
A- Jamais
B- Rarement
C- Quelquefois
D- Souvent
E- Très souvent

\begin{tabular}{|c|c|}
\hline 1. J'éprouve des maux d'estomacs. & $\begin{array}{l}\text { 7. Il m’arrive de m’en faire au-delà de } \\
\text { la raison à propos de choses qui n'en } \\
\text { valent pas la peine. }\end{array}$ \\
\hline $\begin{array}{l}\text { 2. Je travaille ou étudie avec beaucoup de } \\
\text { tension. }\end{array}$ & 8. Je suis calme, je me fâche rarement. \\
\hline $\begin{array}{l}\text { 3. Je m'inquiète passablement à propos de } \\
\text { problèmes qui peuvent survenir. }\end{array}$ & $\begin{array}{l}\text { 9. Il m'arrive de souffrir d'insomnie } \\
\text { causée par l'inquiétude. }\end{array}$ \\
\hline 4. J'ai confiance en moi. & $\begin{array}{l}\text { 10. J'ai de la difficulté à me concentrer } \\
\text { sur un travail. }\end{array}$ \\
\hline $\begin{array}{l}\text { 5. Je suis plus sensible que la majorité des } \\
\text { gens. }\end{array}$ & $\begin{array}{l}\text { 11. Je n’aime pas avoir à affronter des } \\
\text { difficultés ou à prendre une importante } \\
\text { décision. }\end{array}$ \\
\hline $\begin{array}{l}\text { 6. Je me sens anxieux (anxieuse) à propos } \\
\text { de quelque chose ou de quelqu'un. }\end{array}$ & \\
\hline
\end{tabular}

The Canadian Journal of Higher Education

Volume XXXV, No. 4, 2005 